\title{
Gerbera leaf nutritional status as a cut flower cultivated with different doses of nitrogen and calcium
}

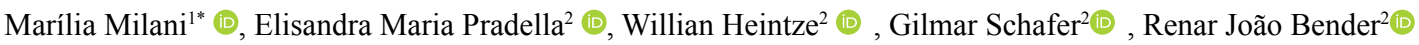 \\ ${ }^{1}$ Universidade Federal de Santa Maria (UFSM), Colégio Politécnico da UFSM, Santa Maria-RS, Brazil. \\ ${ }^{2}$ Universidade Federal do Rio Grande do Sul (UFRGS), Departamento de Horticultura e Silvicultura, Porto Alegre-RS, Brazil.
}

\begin{abstract}
Vegetative tissue analyses might help to diagnose nutritional status of a crop. Foliage diagnosis is an effective method to set up balanced fertilization procedures. The current work aims to evaluate nutrient contents of two gerbera leaf sampling periods as a cut flower cultivated in pots with different doses of nitrogen $(\mathrm{N})$ and calcium $(\mathrm{Ca})$ under greenhouse conditions. The experiment was carried out in a protected environment, shelter type, in a container containing substrate in a $3 \times 3+1$ factorial scheme. Three doses of $\mathrm{N}(0.07,0.15$ or $\left.0.2 \mathrm{~g} \mathrm{~L}^{-1}\right)$ or three doses of $\mathrm{Ca}\left(0.02,0.03\right.$ or $\left.0.04 \mathrm{~g} \mathrm{~L}^{-1}\right)$ were applied every 15 days. Control plants did receive neither $\mathrm{N}$ nor Ca. The substrate was analyzed before and after cultivation, and at the end of production years, as well as completely expanded leaves were collected for nutrient analyses. There was not significant interaction between $\mathrm{N}$ and $\mathrm{Ca}$ doses. Regarding the sampling period or doses of $\mathrm{N}$ and $\mathrm{Ca}$, the determined macronutrient concentrations were in the following order of $\mathrm{N}>\mathrm{K}>\mathrm{Ca}>\mathrm{P}>\mathrm{S}>\mathrm{Mg}$. The micronutrient concentrations were in the following order of $\mathrm{Fe}>\mathrm{Mn}>\mathrm{B}>\mathrm{Zn}>\mathrm{Cu}$. Except for $\mathrm{K}$, all the other nutrient concentrations were in the recommended range for gerberas production.
\end{abstract}

Keywords: cut flower, Gerbera hybrida H., nutrient contents, substrate.

\section{Resumo}

Estado nutricional foliar da gérbera de corte cultivada com diferentes doses de nitrogênio e cálcio

A análise química do tecido vegetal serve como forma de diagnosticar o estado nutricional da cultura. Neste sentido, o diagnóstico foliar torna-se uma ferramenta para se estabelecer programas racionais de adubação. O objetivo do trabalho foi avaliar o teor foliar de nutrientes, ao término do primeiro e segundo ano de produção, de gérbera de corte cultivada com diferentes doses de nitrogênio (N) e cálcio $(\mathrm{Ca})$. O experimento foi conduzido em ambiente protegido, tipo abrigo, em recipiente contendo substrato em esquema fatorial $3 \times 3+1$, sendo três doses de $\mathrm{N}\left(0,07 ; 0,15\right.$ e $\left.0,2 \mathrm{~g} \mathrm{~L}^{-1}\right)$ e de três doses de $\mathrm{Ca}\left(0,02 ; 0,03\right.$ e $\left.0,04 \mathrm{~g} \mathrm{~L}^{-1}\right)$, aplicadas a cada 15 dias, além do controle, sem adubação com $\mathrm{N}$ e Ca. O substrato foi analisado antes e após o cultivo, e ao término dos anos de produção, realizou-se a coleta de folhas completamente expandidas para análise nutricional. Não houve efeito significativo da interação entre as doses de $\mathrm{N}$ e Ca. O teor foliar de potássio (K) encontrou-se abaixo do sugerido na literatura. Independente do período de coleta das folhas e das diferentes doses de $\mathrm{N}$ e de $\mathrm{Ca}$, a concentração dos macronutrientes seguiu a ordem decrescente: $\mathrm{N}>\mathrm{K}>\mathrm{Ca}>\mathrm{P}>\mathrm{S}>\mathrm{Mg}$, e para os micronutrientes: $\mathrm{Fe}>\mathrm{Mn}>\mathrm{B}>\mathrm{Zn}>\mathrm{Cu}$. Os teores foliares dos macronutrientes, com exceção do $\mathrm{K}$, e os teores foliares dos micronutrientes, ao término do primeiro e segundo ano de produção, estão de acordo com o recomendado na literatura para gérbera de corte.

Palavras-chave: flor de corte, Gerbera hybrida H., substrato, teor de nutrientes.

\section{Introduction}

Gerbera (Gerbera hybrida H.) is a commercial flower that is cultivated as a cut flower or in pots, and it is highly enjoyable in the flowers market and ornamental plants in Brazil, offering great diversity of colors, good durability, and resistance to transportation (Santos et al., 2017).
According to Malavolta (2006), plant nutrition and fertilization are vital components to promote good quality resulting in adequate returns to economically important crops. Thus, nitrogen is one of the key nutrients required by plants, since it is involved in essential biochemical functions, such as chlorophyll synthesis, amino acid constituents, amides, proteins, nucleic acids, and nucleotides. On the

https://doi.org/10.1590/2447-536X.v27i4.2378

*Corresponding author: mariliakmilani@gmail.com

Received: Mar 18, 2021 | Accepted: June 21, 2021 | Available online: July 28, 2021

Licensed by CC BY 4.0 (https://creativecommons.org/licenses/by/4.0/)

Area Editor: Paulo Fernandes Boldrin 
other hand, calcium has a central role in cell division and nitrogen absorption at vegetative growth points, as well as being a crucial constituent of the cell wall (Taiz and Zeiger, 2013).

Nutrient analysis of plant tissues aids to diagnosis the nutritional status of a crop. Leaf tissue analyses reflect the effects of soil-plant-climate interactions and managements that might be a strategic tool to set up rational fertilization programs for adequate nutrient supply based on the quantitative variation of elements in plant tissues (Damasceno et al., 2011). However, in Brazil, there is slight information on nitrogen $(\mathrm{N})$ and calcium $(\mathrm{Ca})$ fertilization for gerberas as cut flower grown in containers with organic substrate. Thus, the choice to study these nutrients is due to their functions for plants growth (Milani et al., 2019).

Therefore, the objective of the present work is to evaluate the leaf nutrient contents at the end of the first and second production years of cut gerberas cultivated in containers with different doses of nitrogen and calcium.

\section{Material and Methods}

The experiment was conducted during 28 months in a protected environment, covered with transparent low density polyethylene film. Every day at 30-minute intervals the room temperature and relative humidity were recorded on a thermo-higrograph (Klimalogg Pro $^{\circledR}$ ).

Average room temperature and relative humidity varied according to the season. In the summer months the average temperature was $26.1{ }^{\circ} \mathrm{C}$ and relative humidity was $75.1 \%$. They were $20.1{ }^{\circ} \mathrm{C}$ and $80.2 \%$, respectively in the autumn months and they were $15.4{ }^{\circ} \mathrm{C}$ and $81.8 \%$, respectively during the winter months. Throughout the spring period the average temperature was $21.2^{\circ} \mathrm{C}$ and the relative humidity was $76.2 \%$. Along the summer period when the light intensity was beyond 60 thousand Lux (Mercurio, 2002), an aluminized thermo-reflective net with $50 \%$ shading is used.

Sixteen-week-old gerbera seedlings of the cultivar Dino with an average of seven full developed leaves were purchased from a specialized plantlet grower. The floral stalk and capitulum and the ligulas of the capitulum, referred to as petals, was considered a complete inflorescence. The plantlets were transplanted into plastic containers (one plantlet/pot) of $2.8 \mathrm{~L}$ volume with $17.6 \mathrm{~mm}$ top diameter, $14 \mathrm{~mm}$ base diameter and a height of $15 \mathrm{~cm}$. The pots were filled up to $2.5 \mathrm{~L}$ volume with a Pinus spp. bark-based commercial substrate.

The experiment was conducted in a completely randomized block design in a factorial $3 \times 3+1$, with four replicates and eight plants as experimental unit. The first factor was three doses of $\mathrm{N}\left(0.07,0.15\right.$ or $\left.0.2 \mathrm{~g} \mathrm{~L}^{-1}\right)$ and second factor three doses of $\mathrm{Ca}\left(0.02,0.03\right.$ or $\left.0.04 \mathrm{~g} \mathrm{~L}^{-1}\right)$ and a control treatment (without any addition) had been combined. A total of 320 plants were disposed in a density of 11 plants $\mathrm{m}^{-2}$. The doses of $\mathrm{N}$ and $\mathrm{Ca}$ were based in Hulshof (2008).

Each pot was irrigated by means of a drip irrigation system at a flow rate of $0.46 \mathrm{~L} \mathrm{~h}^{-1}$. During the autumn and winter seasons, the plants were irrigated three times a week for about three minutes in only one cycle a day. In the spring season the plants were irrigated every day and again for one single cycle of three minutes. In the summer season the plants were also irrigated every day, but then divided in three times a day in a total of seven minutes of water delivery. The irrigation water presented an average $\mathrm{pH}$ of 6.53 and $116.20 \mu \mathrm{S} \mathrm{cm}^{-1}$ conductivity.

After 27 days of transplanting (DOT), fertilization of the pots started and ended after 833 DOT. The fertilizers were all diluted in water and $50 \mathrm{~mL}$ were manually applied to every pot at 15 days intervals. The doses of $\mathrm{N}$ and $\mathrm{Ca}$ were applied in the form ammonium nitrate $30 \%$ total $\mathrm{N}: 15 \% \mathrm{NO}_{3}^{-}$and $\left.15 \% \mathrm{NH}_{4}^{+}\right)$and calcium nitrate $(15.5 \%$ $\mathrm{NO}_{3}^{-}$plus $19 \% \mathrm{Ca}$ ). At the end of the experiment the total amounts of $\mathrm{N}$ for each pot were $3.94,8.58$ and $11.83 \mathrm{~g} \mathrm{~L}^{-1}$. The total amounts of $\mathrm{Ca}$ applied to every experimental unit were $0.93,186$ and $2.55 \mathrm{~g} \mathrm{~L}^{-1}$. All the experimental units received a complementary fertilization of potassium $(\mathrm{K})$, phosphorus $(\mathrm{P})$ and magnesium $(\mathrm{Mg})$ during the growth period aggregate of $0.08,0.32$ and $0.02 \mathrm{~g} \mathrm{~L}^{-1}$, respectively.

The reproductive period was considered as starting after 91 DOT when $80 \%$ of the plants displayed a perceptible floral button of $\pm 1 \mathrm{~cm}$. In meanwhile, macro and micronutrients supply were recalculated, and the plants started to receive them. The total amounts of $\mathrm{K}, \mathrm{P}$ and $\mathrm{Mg}$ for each experimental unit were 1.63, 8.77 and 0.61 $\mathrm{g} \mathrm{L}^{-1}$, respectively. Additionally, $5.1 \mathrm{~g} \mathrm{~L}^{-1} \operatorname{Rexolin}^{\circledR}$ (water soluble micronutrients) were applied to the experimental units. Rexolin ${ }^{\circledR}$ contains $11.6 \% \mathrm{~K}_{2} \mathrm{O}, 1.28 \% \mathrm{~S}, 0.86 \% \mathrm{Mg}$, $2.1 \% \mathrm{~B}, 0.36 \% \mathrm{Cu}, 2.66 \% \mathrm{Fe}, 2.48 \% \mathrm{Mn}, 0.036 \% \mathrm{Mo}$ and $3.38 \% \mathrm{Zn}$. The source for $\mathrm{K}$ was $\mathrm{K}$ chloride $(\mathrm{KCl}$ containing $60 \% \mathrm{~K}_{2} \mathrm{O}$ ) for $\mathrm{P}$ the source was monopotassium phosphate (MKP) containing $52 \% \quad \mathrm{P}_{2} \mathrm{O}_{5}$ and $34 \% \quad \mathrm{~K}_{2} \mathrm{O}$ and for magnesium the source was magnesium sulphate containing $9 \% \mathrm{Mg}$.

The substrate was analyzed before and after 28 months of gerberas cultivation period. Samples of every treatment and block were analyzed at the Substrate Laboratory of the Faculty of Agronomy (UFRGS). Conductivity $\left(\mathrm{mS} \mathrm{cm}^{-1}\right)$ and $\mathrm{pH}$ in water were determined via dilution method 1:5 (Brasil, 2007). Physical analyses such as dry density (kg $\left.\mathrm{m}^{-3}\right)$, total porosity $(\%)$, aeration space $(\%)$, available water $(\%)$ and remaining water $(\%)$ were determined according to De Boodt and Verdonck (1972).

At the end of the first and second year of trial (384 and 849 DOT), fifteen completely expanded leaves were sampled (adapted from the Comissão de Química e Fertilidade do Solo - RS/SC, 2016) and taken to the laboratory to determine macro and micronutrients contents according to the methodology of Tedesco et al. (1995).

Data for total nutrient contents were analyzed as trifactorial because sampling of leaves was considered a factor of variation besides the doses of $\mathrm{N}$ and $\mathrm{Ca}$. When the double interactions (periods versus doses of $\mathrm{N}$ or periods versus doses of $\mathrm{Ca}$ ) were not significant only the main effects were evaluated. The data were submitted to analysis of variance at $p<0.05$ and regression analysis for $\mathrm{N}$ and Ca doses. The statistical program SISVAR (Ferreira, 
2021). was used for the statistical analyses and linear Pearson correlation was determined for nutrient contents of gerbera leaves at 5\% significance using the software Action (Estatcamp, 2021).

\section{Results and Discussion}

There was not significant effect on the interaction (doses of $\mathrm{N}$ versus doses of $\mathrm{Ca}$ ) for the chemical and physical variables of the substrates. Therefore, only the main effects were determined. Concerning the chemical characteristics of the substrate, the conductivity was influenced by the tested doses of $\mathrm{N}$ and $\mathrm{Ca}$ fertilization (Figure 1A and B). The tested concentrations of $\mathrm{N}$ and $\mathrm{Ca}$ also affected the $\mathrm{pH}$ values (Figure $1 \mathrm{C}$ ), indicating that the gerbera cultivation parameters changed compared to the beginning of cultivation since the $\mathrm{pH}$ value was 6.37 and the salinity was $0.28 \mathrm{mS} \mathrm{cm}^{-1}$. The conductivity of the substrate had a similar increasing trend for $\mathrm{N}$ and $\mathrm{Ca}$ indicating that their highest doses $\left(0.2 \mathrm{~g} \mathrm{~L}^{-1} \mathrm{~N}\right.$ and $0.04 \mathrm{~g} \mathrm{~L}^{-1} \mathrm{Ca}$, at 15 days intervals) presented the highest values of conductivity: 0.81 and $0.78 \mathrm{mS} \mathrm{cm}^{-1}$, respectively.
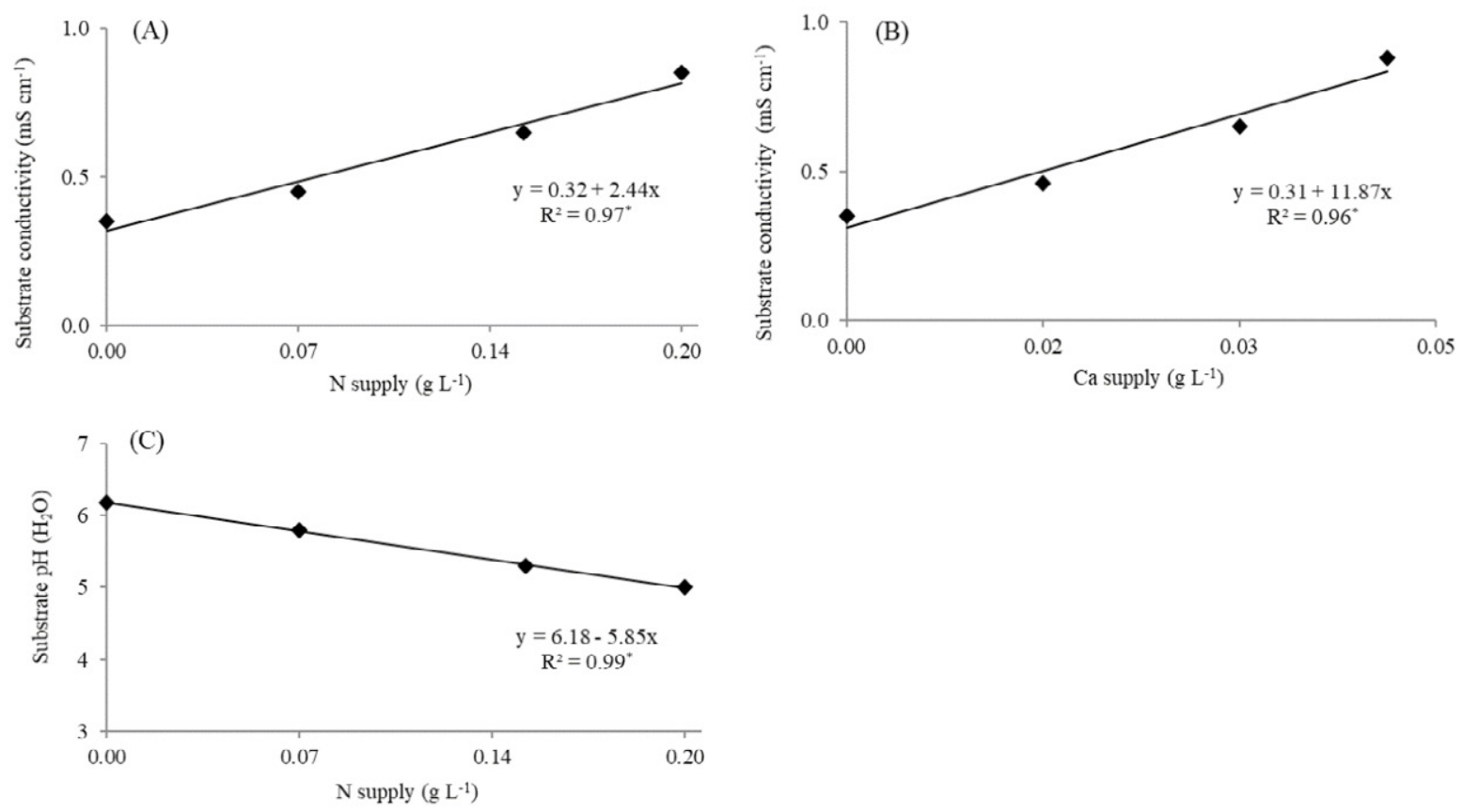

Figure 1. Substrate chemical characteristics after 28 months of gerbera cultivation. Substrate conductivity (A) and substrate $\mathrm{pH}$ (B) in the function of $\mathrm{N}$ doses supply. Substrate conductivity (C) in the function of Ca doses supply. The $\mathrm{N}$ and $\mathrm{Ca}$ were supplied at 15 days intervals.

*Significant at 5\% probability

The obtained results are in accordance with those of Mercurio (2002) who recommends that substrate for gerbera as cut flower should have a conductivity below $0.9 \mathrm{mS} \mathrm{cm}^{-1}$ in $1: 5$ diluted solutions. The $\mathrm{pH}$ value of the substrate realized opposite conductivity trend for $\mathrm{N}$ doses (Figure 1C). A linear negative adjustment was noticed with the highest doses of $\mathrm{N}$ resulted in a lower $\mathrm{pH}$ value (4.98). This is probably might attributed to using ammonium nitrate reduced the $\mathrm{pH}$ value of the substrate. Also, ammonia nitrogen after biological oxidation by the nitrification process results in soil acidification. Calcium doses did not present a significant polynomial adjustment. According to Mercurio (2002), the ideal $\mathrm{pH}$ for cut gerbera cultivation is situated between 5.5 and 6.0. Ludwig et al. (2020) concluded that substrates with extreme $\mathrm{pH}$ values, below 5.0 or over 7.0 are not adequate for gerbera plants. Inadequate $\mathrm{pH}$ could influence the availability of nutrients since at $\mathrm{pH}$ values below 5.0 deficiency symptoms of $\mathrm{N}, \mathrm{K}, \mathrm{Ca} \mathrm{Mg}$ and $\mathrm{B}$ might come into sight. On the contrary, at $\mathrm{pH}$ values over 6.5 problems with the availability of $\mathrm{P}, \mathrm{Fe}, \mathrm{Mn}, \mathrm{Zn}$ and $\mathrm{Cu}$ might be expected (Kämpf, 2005).

With regards to physical properties of the substrates, not significant polynomial adjustment for $\mathrm{N}$ and $\mathrm{Ca}$ doses could be calculated. However, there were variations on the average values determined before and after the end of cultivation period of the gerberas, which is a predictable result when using organic substrates (Table 1). 
Table 1. Physical characteristics of the substrate at the beginning of the experiment and after 28 months of gerbera cultivation for cut flower cv. Dino.

\begin{tabular}{|c|c|c|}
\hline $\begin{array}{c}\text { Physical characteristics } \\
\text { of the substrate }\end{array}$ & At experimental set up & After 28 months of cultivation \\
\hline DD $\left(\mathrm{kg} \mathrm{m}^{-3}\right)$ & 342.76 & 337.96 \\
\hline TP (\%) & 77.46 & 86.23 \\
\hline AS (\%) & 27.22 & 37.22 \\
\hline AW (\%) & 14.60 & 10.50 \\
\hline RW (\%) & 35.65 & 38 \\
\hline
\end{tabular}

$\mathrm{DD}=$ dry density; $\mathrm{TP}=$ total porosity $\mathrm{AS}=$ aeration space; $\mathrm{AW}=$ available water; $\mathrm{RW}=$ remaining water.

Dry density (DD) of the substrate at the experimental set up had an average value of $342.76 \mathrm{~kg} \mathrm{~m}^{-3}$ and it reduced to $337.96 \mathrm{~kg} \mathrm{~m}^{-3}$ after 28 months experiment duration. These values of DD are in accordance with Kämpf (2005) who recommended that DD values varying from 250 to 400 $\mathrm{kg} \mathrm{m}^{-3}$ per pot.

The total porosity (TP) was increased almost by $10 \%$ after gerberas cultivation. The TP value of $86.23 \%$ is very close to that value suggested by De Boodt and Verdonck (1972) as ideal for a substrate $(85 \%$ of its volume as pores).

A reduction of available water (AW) was observed after the end of the gerbera's cultivation period. The AW values ranged between $25 \%$ and $35 \%$ are considered ideal for gerberas cultivation (De Boodt and Verdonck, 1972). The aeration space (AS) realized an increase of $10 \%$ by the end of cultivation period. The average value of AS was $37.22 \%$ which is higher than those values $(20 \%$ to $30 \%)$ suggested by De Boodt and Verdonck (1972). They recommend that the remaining water of the substrate should be between $20 \%$ and $30 \%$ and the substrate of the present experiment had an average value of $35.65 \%$ at the experimental set up and $38 \%$ after the end of the cultivation period.

The variations of substrate physical characteristics after finishing the experiment might be due to the long cultivation period resulting in a rearrangement of particles either because of higher accommodation of the substrate or because of its decomposition. The main effects of that reorganization are increases on macropore volume, boosting aeration space, and ultra-micro-pores, enhancing the remaining water so both characteristics raises total porosity (Schafer et al., 2008).

As for the gerbera leaf contents of macro and micronutrients, the triple interaction (sampling period $\mathrm{x}$ nitrogen doses $\mathrm{x}$ calcium doses) as well as the double interaction (doses of nitrogen $\mathrm{x}$ doses of calcium) were not significant. When double interactions (sampling period $\mathrm{x}$ nitrogen doses and sampling period $x$ calcium doses) were not significant only the main effect of the fertilizer doses were examined.

Regarding foliar content of $\mathrm{N}$, a significant effect of the interaction of sampling periods and $\mathrm{N}$ doses was observed. Analyzing the $\mathrm{N}$ doses on every period, illustrated that it was possible to determine in two periods a significant second order adjustment of the observed values. After 489 DOT, the maximum $\mathrm{N}$ contents of $26.1 \mathrm{~g} \mathrm{~kg}^{-1}$ were recorded when $0.14 \mathrm{~g} \mathrm{~N} \mathrm{~L}^{-1}$ substrate was applied every 15 days. After 849 DOT, the maximum content $\left(34.34 \mathrm{~g} \mathrm{~kg}^{-1}\right.$ ) was noticed when $0.13 \mathrm{~g} \mathrm{~L}^{-1}$ of $\mathrm{N}$ was supplied to the gerberas every 15 days (Figure $2 \mathrm{~A}$ ). 

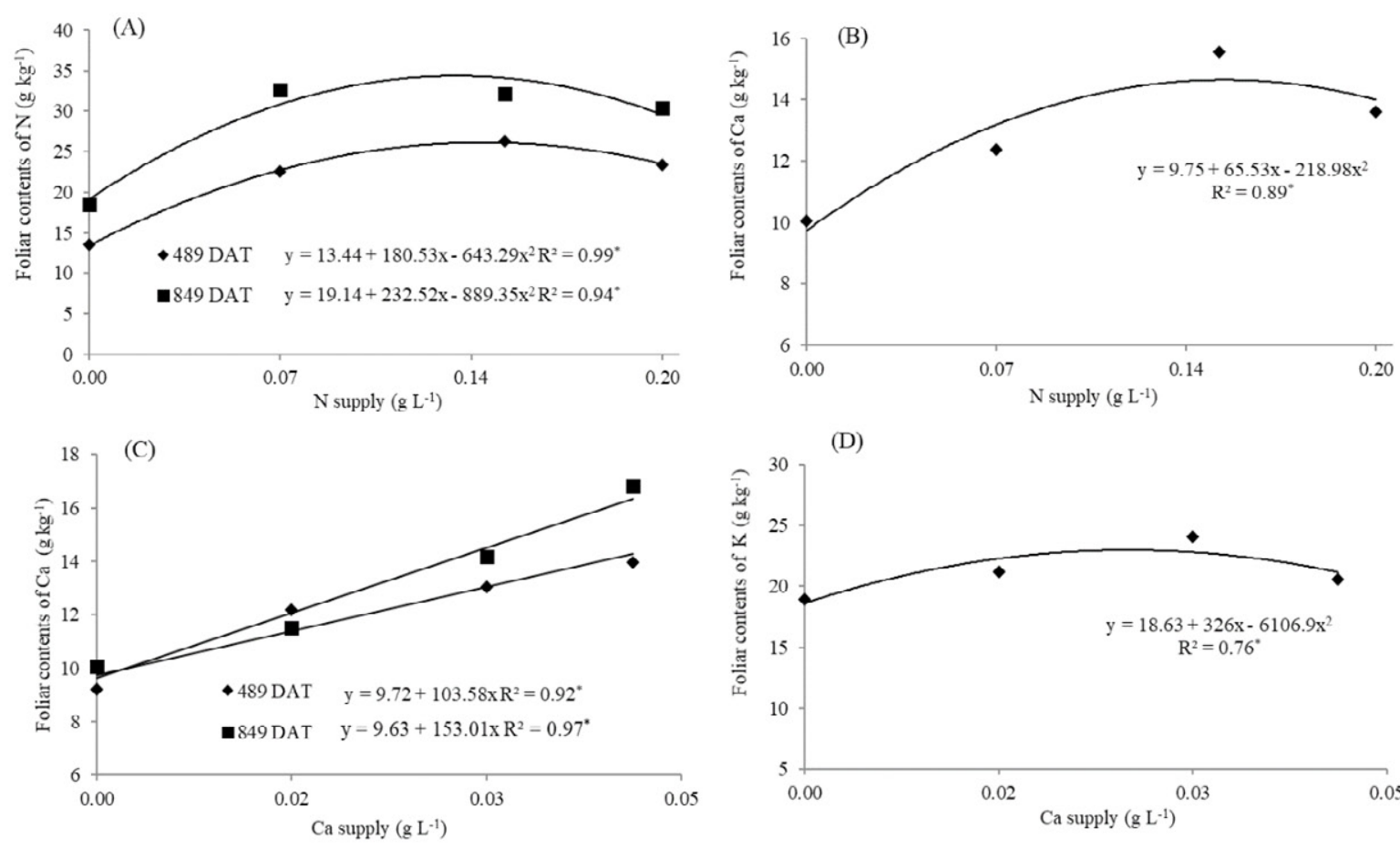

(D)
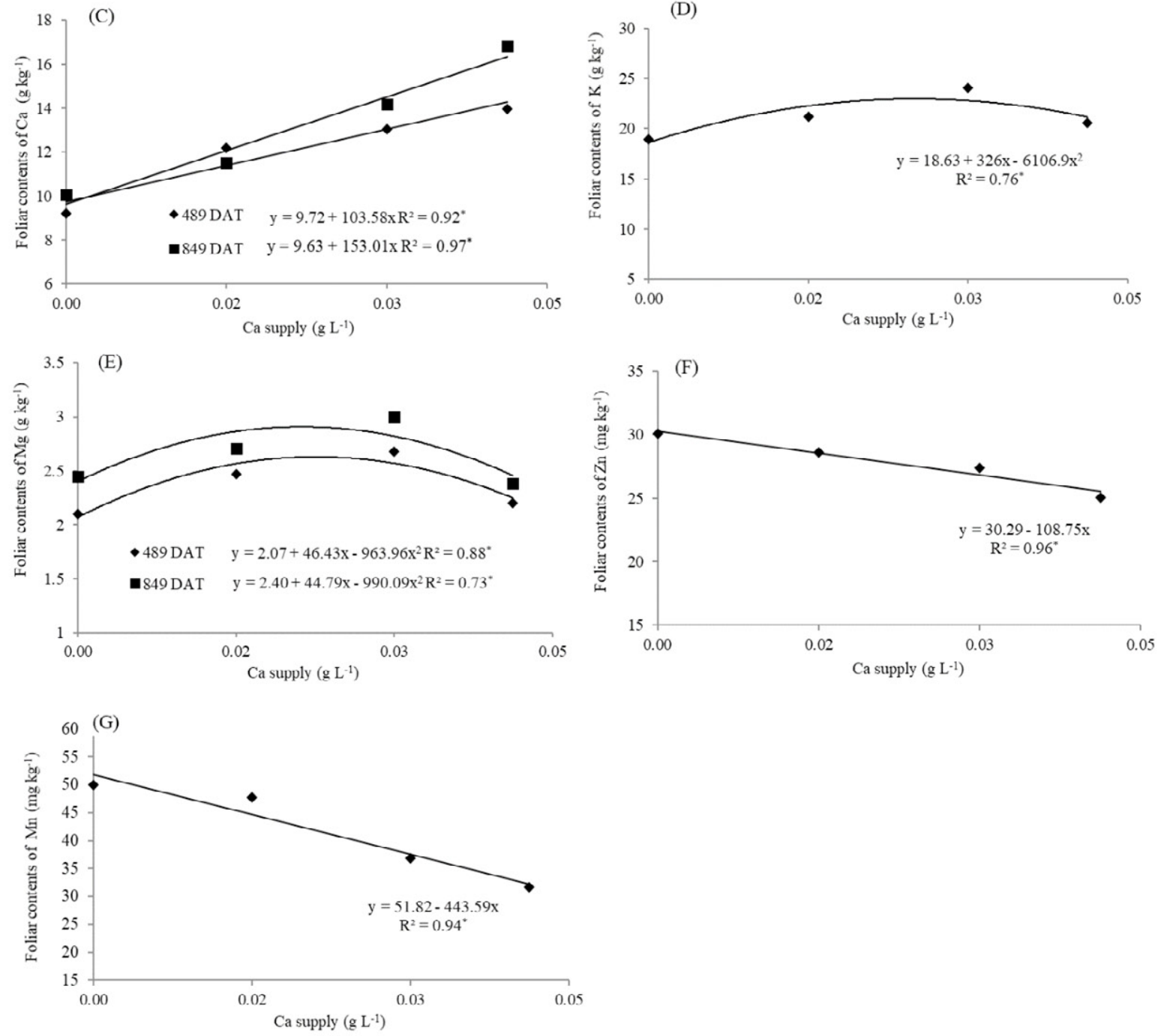

Figure 2. Gerberas foliar content of $\mathrm{N}(\mathrm{A})$ and $\mathrm{Ca}(\mathrm{B})$ in the function of $\mathrm{N}$ doses supply and contents of $\mathrm{Ca}(\mathrm{C})$, $\mathrm{K}(\mathrm{D}), \mathrm{Mg}(\mathrm{E}), \mathrm{Zn}(\mathrm{F}), \mathrm{Mn}(\mathrm{G})$ in the function of Ca doses supply. The $\mathrm{N}$ and $\mathrm{Ca}$ were supplied at 15 days intervals.

${ }^{*}$ Significant at $5 \%$ probability. 
These results are in accordance to those of Hulshof (2008) who indicated that $\mathrm{N}$ concentration ranged between 22 and $36 \mathrm{~g} \mathrm{~kg}^{-1}$. These values are slightly higher than those suggested by Mercurio (2002) who mentioned value of 27 to $31 \mathrm{~g} \mathrm{~kg}^{-1}$. In the control plants the average $\mathrm{N}$ contents was $13.44 \mathrm{~g} \mathrm{~kg}^{-1}$ after 489 DOT and $19.14 \mathrm{~g} \mathrm{~kg}^{-1}$ after 849 DOT (Figure 2A). These values indicated that the substrate was the source for $\mathrm{N}$ nutrient with low $\mathrm{C} / \mathrm{N}$ ratio. In these plants, since the foliar $\mathrm{N}$ content was below the recommended for gerberas, symptoms of $\mathrm{N}$ deficiency could be visualized (smaller and yellowish leaves). There was not significant interaction between periods of retrieval of samples and doses of $\mathrm{Ca}$ for leaf contents of nitrogen. The analyses of $\mathrm{Ca}$ doses indicated that there was not significant polynomial adjustment. The average value of $\mathrm{N}$ was equal to $25.12 \mathrm{~g}$ $\mathrm{kg}^{-1}$, which is in accordance to the recommendations for gerberas production. Malavolta (2006) stated that added Ca has no effect on the foliar contents of $\mathrm{N}$.

The foliar content of $\mathrm{Ca}$ showed not significant interaction between periods of sample retrieval and doses of $\mathrm{N}$. The regression analysis for $\mathrm{N}$ doses resulted in a significant second order adjustment (Figure 2B). With a dose of $0.15 \mathrm{~g} \mathrm{~L}^{-1}$ of $\mathrm{N}$ at every 15 days the highest $\mathrm{Ca}$ contents was equal to $14.65 \mathrm{~g} \mathrm{~kg}^{-1}$. The synergistic effect might be attributed to the elevation of the cationic exchange capacity of the roots promoted by $\mathrm{N}$, allowing the plants to absorb more Ca (Malavolta, 2006).

On the other hand, the foliar content of $\mathrm{Ca}$ was influenced significantly by the interaction of the periods of sample retrieval and the $\mathrm{Ca}$ doses (Figure 2C). After 489 and 849 DOT, the leaves Ca contents was $13.86 \mathrm{~g} \mathrm{~kg}^{-1}$ and $15.75 \mathrm{~g} \mathrm{~kg}^{-1}$, respectively, at $0.04 \mathrm{~g} \mathrm{~L}^{-1}$ of $\mathrm{Ca}$ applied every 15 days. These values are considered adequate for gerberas growth (Hulshof, 2008) and slightly below the lowest limit of $16.6 \mathrm{~g} \mathrm{~kg}^{-1}$ of $\mathrm{Ca}$ which was indicated by Mercurio (2002).

In the control plants an average concentration of 9.68 $\mathrm{g} \mathrm{kg}^{-1}$ of $\mathrm{Ca}$ was found in the leaves, indicating that the substrate was the source of $\mathrm{Ca}$ for gerbera plants. In the control plants symptoms of Ca deficiency as described by Hulshof (2008) were observed (wrinkled and curled new leaves and afterwards chlorotic and with necrosis at the edges and apex).

For foliar content of $\mathrm{P}$, not significant interactions between sample retrieval and $\mathrm{N}$ doses as well as the $\mathrm{Ca}$ doses were observed. Regression analyses for $\mathrm{N}$ and $\mathrm{Ca}$ doses showed not significant polynomial adjustment. The average foliar content of $\mathrm{P}$ was $2.98 \mathrm{~g} \mathrm{~kg}^{-1}$. This value is considered adequate according to Mercurio (2002) and Hulshof (2008). They suggested values in the range of 1.9 up to $3.5 \mathrm{~g} \mathrm{~kg}^{-1}$ and 2 up to $4 \mathrm{~g} \mathrm{~kg}^{-1}$ of $\mathrm{P}$, respectively.

Regarding foliar content of $\mathrm{K}$, also not significant interaction between sample retrieval and doses of $\mathrm{N}$ and $\mathrm{Ca}$ were observed. In the analysis of $\mathrm{N}$ doses, not significant polynomial adjustment could be calculated. The average value for $\mathrm{K}$ was $23.19 \mathrm{~g} \mathrm{~kg}^{-1}$. In the analysis for $\mathrm{Ca}$ doses, a second order adjustment was determined (Figure $2 \mathrm{D}$ ). A maximum content of $22.9 \mathrm{~g} \mathrm{~kg}^{-1}$ of $\mathrm{K}$ was obtained with a dose of $0.03 \mathrm{~g} \mathrm{~L}^{-1}$ of Ca substrate. At low concentrations of
$\mathrm{Ca}^{2+}$ a synergistic effect of $\mathrm{K}^{+}$uptake takes place. Otherwise, at high $\mathrm{Ca}^{2+}$ concentrations a competitive inhibitory effect on $\mathrm{K}^{+}$is observed (Malavolta, 2006). Therefore, the $\mathrm{K}$ concentrations reduced via a competitive inhibitory effect of $\mathrm{Ca}^{2+}$ ions as with increasing $\mathrm{Ca}$ concentrations a higher content of $\mathrm{Ca}$ in the leaves was determined while $\mathrm{K}$ contents reduced after a dose of $0.03 \mathrm{~g} \mathrm{~L}^{-1}$ of Ca substrate.

Mercurio (2002) suggested that the appropriate $\mathrm{K}$ contents in gerberas were in the range of 31 to $36 \mathrm{~g} \mathrm{~kg}^{-1}$. On the other hand, Hulshof(2008) proposed K contents between 32 up to $52 \mathrm{~g} \mathrm{~kg}^{-1}$. The $\mathrm{K}$ concentrations determined in the present experiment remained below the recommended values. However, no deficiency symptoms were observed. Taiz and Zeiger (2013) describe K deficiency as marginal chlorosis in fully developed leaves that later could evolve to necrosis on leaf apex, leaf margins and between leaf ribs.

The foliar content of $\mathrm{Mg}$ showed not significant interaction of leaf sampling periods and doses of $\mathrm{N}$. The average value for $\mathrm{Mg}$ in the leaves was $2.69 \mathrm{~g} \mathrm{~kg}^{-1}$. Regression analyses showed not significant polynomial adjustment for $\mathrm{Mg}$ content. As for the Ca doses, a significant interaction between leaf sampling periods was observed. A second order adjustment for Ca doses on every sampling period was calculated for $\mathrm{Mg}$ content (Figure 2E). The maximum foliar content of $\mathrm{Mg}$ every 15 days interval at $0.02 \mathrm{~g} \mathrm{~L}^{-1}$ of Ca substrate were 2.61 and $2.9 \mathrm{~g} \mathrm{~kg}^{-1}$ after 484 and 849 DOT, respectively. Even in plants in which a foliar content of $\mathrm{Mg}$ is reduced, the element is considered in the adequate range for gerberas: $2.0-4.0 \mathrm{~g} \mathrm{~kg}^{-1}$ (Hulshof, 2008).

The foliar content of $\mathrm{S}$ in the gerbera leaves showed not significant interaction of periods of leaf sampling and doses of either $\mathrm{N}$ or $\mathrm{Ca}$. The regression analysis for $\mathrm{N}$ and $\mathrm{Ca}$ showed not significant polynomial adjustment. The average $\mathrm{S}$ content in the gerberas was $2.83 \mathrm{~g} \mathrm{~kg}^{-1}$ and it is in the range $\left(1.5-3.0 \mathrm{~g} \mathrm{~kg}^{-1}\right)$ that recommended by Hulshof (2008).

Significant correlations between foliar contents of some macronutrients were determined after 489 days or 849 days of cultivation. These actions indicated that one nutrient was positively affected the concentration of another nutrient in the leaves of gerbera plants. After 489 DOT, the correlations were: $\mathrm{P}$ and $\mathrm{K}(\mathrm{r}=0.56), \mathrm{P}$ and $\mathrm{S}(\mathrm{r}=0.50)$ and $\mathrm{Mg}$ and $\mathrm{S}$ $(\mathrm{r}=0.51)$. After 849 DOT, the correlations were: $\mathrm{P}$ and K $(\mathrm{r}$ $=0.75), \mathrm{P}$ and $\mathrm{Mg}(\mathrm{r}=0.52), \mathrm{P}$ and $\mathrm{S}(\mathrm{r}=0.91), \mathrm{K}$ and $\mathrm{S}(\mathrm{r}$ $=0.80)$ and $\mathrm{Mg}$ and $\mathrm{S}(\mathrm{r}=0.53)$.

Concerning sampling retrieval and of the tested doses of $\mathrm{N}$ and $\mathrm{Ca}$, the macronutrients concentrations in the gerbera leave plants could be arranged in the descending order of $\mathrm{N}>\mathrm{K}>\mathrm{Ca}>\mathrm{P}>\mathrm{S}>\mathrm{Mg}$. This trend was differed than that observed by Damasceno et al. (2011) who stated the following order for macronutrients of $\mathrm{K}>\mathrm{N}>\mathrm{Ca}>\mathrm{Mg}>\mathrm{P}>\mathrm{S}$. These discrepancies are expected because nutrient content might vary depending on the cultivation conditions such as soil or substrate type, temperature, humidity and even the cultivar used (Hulshof, 2008). In addition, plants of different species or genotypes might impart different absorption rates because of anatomical dissimilarities.

Concerning micronutrients, for none-analyzed elements double interactions (sampling period versus 
doses of $\mathrm{N}$ or $\mathrm{Ca}$ ) were significant. Likewise, for none of the micronutrients a polynomial adjustment was observed either for $\mathrm{N}$ or $\mathrm{Ca}$ doses. The average $\mathrm{Cu}$ content was 9.34 $\mathrm{mg} \mathrm{kg}{ }^{-1}$. These values in accordance with those suggested by Mercurio (2002) and Hulshof (2008) as adequate value which ranged from 8 to $12 \mathrm{mg} \mathrm{kg}^{-1}$ and from 5 to $12 \mathrm{mg} \mathrm{kg}^{-1}$ of $\mathrm{Cu}$, respectively.

The average value of $\mathrm{Fe}$ in gerbera leaves in the present experiment was $308.41 \mathrm{mg} \mathrm{kg}^{-1}$. There is no consensus about the ideal $\mathrm{Fe}$ concentration in gerberas. Mercurio (2002) suggested that a concentration of 450 to $500 \mathrm{mg} \mathrm{kg}^{-1}$ of Fe while Hulshof (2008) found a range of 90 to $140 \mathrm{mg}$ $\mathrm{kg}^{-1}$ of $\mathrm{Fe}$ content in gerberas leaves.

For foliar $\mathrm{Zn}$ leaf content of $\mathrm{Zn}$, the regression analysis showed not significant adjustment in response to doses of $\mathrm{N}$. The average content of $\mathrm{Zn}$ in leaves was $26.73 \mathrm{mg} \mathrm{kg}^{-1}$. In respect to $\mathrm{Ca}$ doses, a significant linear adjustment was viable (Figure 2F). The $\mathrm{Zn}$ contents of the gerbera leaves diminished as the $\mathrm{Ca}$ doses increases, which means that the $\mathrm{Zn}$ content was high in the control plants (30.29 mg kg-1). Beyond that, a negative correlation was recorded $(r=-0.69)$ among leaf contents of $\mathrm{Ca}$ and $\mathrm{Zn}$. According to Malavolta (2006) there is competitive inhibition of $\mathrm{Ca}^{2+}$ ions over $\mathrm{Zn}^{2+}$ ions. Furthermore, there is no agreement on the recommendations for ideal concentration of $\mathrm{Zn}$ in leaves. Mercurio (2002) suggested values of 6 to $8 \mathrm{mg} \mathrm{kg}^{-1}$ of $\mathrm{Zn}$. On the other hand, Hulshof (2008) found a range of 25 to $80 \mathrm{mg} \mathrm{kg}^{-1}$ of $\mathrm{Zn}$ which is compatible with present experiment values.

Regression analyses of $\mathrm{Mn}$ contents showed not significant adjustment for $\mathrm{N}$ doses. The average value of $\mathrm{Mn}$ in gerbera leaves was $44.8 \mathrm{mg} \mathrm{kg}^{-1}$. This concentration is equivalent to that recommended by Mercurio (2002) and Hulshof (2008) who indicated that Mn ideal values of 40 to $50 \mathrm{mg} \mathrm{kg}^{-1}$ and 30 to $100 \mathrm{mg} \mathrm{kg}^{-1}$, respectively. $\mathrm{Ca}$ doses presented a linear negative adjustment (Figure $2 \mathrm{G})$. Increases $\mathrm{Ca}$ doses resulted in reduced $\mathrm{Mn}$ contents in the leaves. Malavolta (2006) stated that $\mathrm{Mn}^{2+}$ has similar chemical properties of the $\mathrm{Ca}^{2+}$ ion so $\mathrm{Ca}$ ions leads to lower absorption of $\mathrm{Mn}$, justifying the negative correlation $(r=-0.80)$ of $\mathrm{Ca}$ and $\mathrm{Mn}$ contents.

There was also a significant correlation between the contents of $\mathrm{Zn}$ and $\mathrm{Mn}$ at the retrieval of leaf tissues after $489(\mathrm{r}=0.94)$ and after $849(\mathrm{r}=0.88)$ days after transplanting. These correlations pointed out the positive relation of these micronutrients in the gerbera leaves.

For foliar content of $\mathrm{B}$, no adjustment resulted statistically significant was found for neither $\mathrm{N}$ nor $\mathrm{Ca}$ supply to the plants. The average value for $\mathrm{B}$ contents was $40.7 \mathrm{mg} \mathrm{kg}^{-1}$, which is similar to that obtained by Hulshof (2008) since it ranged from 20 to $50 \mathrm{mg} \mathrm{kg}^{-1}$.

Referring to the different doses of $\mathrm{N}$ and $\mathrm{Ca}$, the concentrations of micronutrients in the leaves of the gerbera plants followed the descending order of $\mathrm{Fe}>\mathrm{Mn}>\mathrm{B}>\mathrm{Zn}>\mathrm{Cu}$. This sequence is similar to the conclusion of Guerrero et al. (2016).

\section{Conclusions}

Regardless of the leaf sampling period and the different doses of $\mathrm{N}$ and $\mathrm{Ca}$ applied every 15 days to gerbera cultivated in containers as cut flower, the leaf contents in descending order at the end of the first and second year of production were: $\mathrm{N}>\mathrm{K}>\mathrm{Ca}>\mathrm{P}>\mathrm{S}>\mathrm{Mg}$, e: $\mathrm{Fe}>\mathrm{Mn}>\mathrm{B}>\mathrm{Zn}>\mathrm{Cu}$.

\section{Author Contribution}

MM: responsible for the implementation, conduct, evaluation of the experiment and writing of the scientific article. EMP: responsible for the implementation, conduct, evaluation of the experiment and writing of the scientific article. WH: responsible for the implementation, conduct, evaluation of the experiment and writing of the scientific article. GS: advisor, participating in the conception and planning of the experiment and in the correction of the scientific article. RJB: advisor, participating in the conception and planning of the experiment and in the correction of the scientific article.

\section{Acknowledgements}

The authors are thankful to the National Council for Scientific and Technological Development $(\mathrm{CNPq})$ for the scholarship granted to the first author.

\section{References}

BRASIL. Instrução Normativa $\mathrm{n}^{\circ} 17$, de 21 de maio de 2007. Aprova os métodos analíticos oficiais para análise de substratos e condicionadores de solos. DOU, 24/05/2007, Seção 1, p.8, 2007.

COMISSÃO DE QUÍMICA E FERTILIDADE DO SOLO - RS/SC. Manual de adubação e calagem para os Estados do Rio Grande do Sul e Santa Catarina. Porto Alegre: Sociedade Brasileira de Ciência do Solo - Núcleo Regional Sul. [s.1.]: Comissão de Química e Fertilidade do Solo - RS/SC, 2016. 376p.

DAMASCENO, L.M.O.; JÚNIOR, A.S.A.; GHEYI, H.R.; DIAS, N.S.; SILVA, C.O. Composição nutricional foliar da gérbera irrigada com efluente doméstico tratado. Revista Caatinga, v.24, n.2, p.121-128, 2011.

DE BOODT, M.; VERDONCK, O. The physical properties of the substrates in horticulture. Acta Horticulturae, v.26, p.37-44, 1972.

ESTATCAMP (2021). Available at: <https://www. estatcamp.com.br/>. Accessed on: Feb $1^{\text {st }} 2021$. 
FERREIRA, D.F. SISVAR: Sistema de análise de variância. Versão 5.6. Lavras, Universidade Federal de Lavras, 2021. Available at: <http://www.dex.ufla.br/ danielff/ programas/sisvar.html>. Accessed on: Feb $3^{\text {rd }} 2021$.

GUERRERO, A.C.; FERNANDES, D.M.; LUDWIG, F.; FERREIRA, G.A. Teor e acúmulo de micronutrientes em gérbera de vaso em função de fontes e doses de potássio. Revista Verde, v.11, n.4, p.26-33, 2016. http://dx.doi. org/10.18378/rvads.v11i4.4461

HULSHOF, T. Gérberas: sobre as desordens nutricionais e adubação na cultura da gérbera de corte. Holambra: Editora Setembro, 2008. 48p.

KÄMPF, A. Produção comercial de plantas ornamentais. Guaíba: Agrolivros, 2005. 256p.

LUDWIG, F.; FERNANDES, D.M.; GUERRERO, A.C.; FERREIRA, G.A.; POHLMANN, V. Neutralização da acidez em substrato de casca de pinus com diferentes granulometrias. Revista Eletrônica Científica da UERGS, v.6, n.1, p.01-08, 2020. http://dx.doi.org/0.21674/24480479.61.01-08

MALAVOLTA, E. Manual de nutrição de plantas. Piracicaba, Livroceres, 2006. 638p.
MERCURIO, G. Gérbera cultivation in greenhouse. The Netherlands: Schreurs, 2002. 206p.

MILANI, M.; PRADELLA, E.M.; HEINTZE, W.; SCHAFER, G.; BENDER, J.R. The effects of supplemental nitrogen and calcium on the quality and postharvest life of cut gerbera. Ornamental Horticulture, v.25, n.4, p.365373, 2019. http://dx.doi.org/10.1590/2447-536x.v25i4.2028.

SANTOS, F.T.; COSTA, L.A.M.; SILVA, M.S.; COSTA, M. Sensory analysis and postharvest of potted based on fertilization. Ornamental Horticulture, v.23, n.1, p.30$37,2017$.

SCHAFER, G.; SOUZA, P.V.D.; KOLLER, O.C.; SCHWARZ, S.F. Physical and chemical properties of substrates to cultivate seedling of citrus rootstocks. Communications in Soil Science and Plant Analysis, v.39, p.1067-1079, 2008. http://dx.doi. org/10.1080/00103620801925547

TAIZ, L.; ZEIGER, E. Fisiologia vegetal. 5ed. Porto Alegre: Artmed, 2013. 918p.

TEDESCO, M.J.; GIANELLO, C.; BISSANI, C.A.; BOHNEN, H.; VOLKWEISS, S.J. Análise de solo, plantas e outros materiais. 2ed. Porto Alegre: Departamento de Solos, 1995. 174p. 